\title{
CONHECIMENTO, INFORMAÇÃO E TECNOLOGIA
}

$\mathrm{C}$ ada época vivida pela humanidade tem características próprias, que a distinguem de épocas anteriores, como épocas anteriores se distinguiram de épocas anteriores e assim sucessivamente. E, em cada uma dessas épocas, houve, dialeticamente, aspectos positivos e negativos. Assim acontece hoje.

As distinções entre as épocas podem ser marcadas, entre outros aspectos, pela formação e expansão dos mercados, que determinou pólos de concentração, baseados na busca permanente de acumulação do capital. Otávio Ianni, em As economias-mundo, aponta as diversidades e desigualdades com as quais cada totalidade se constitui. Segundo o autor, cada época "é um todo em movimento, heterogêneo, integrado, tenso e antagônico. É sempre problemático, atravessado pelos movimentos de integração e fragmentação. Suas partes, compreendendo nações e nacionalidades, grupos e classes sociais, movimentos sociais e partidos políticos, conjugam-se de modo desigual, articulado e tenso, no âmbito do todo. Simultaneamente, esse todo confere outros e novos significados e movimentos às partes. Anulam-se e multiplicam-se os espaços e os tempos, já que se trata de uma totalidade heterogênea, contraditória, viva, em movimento"'.

Fredric Jameson aponta três períodos de expansão capitalista, caracterizados por rupturas "tecnológicas". Segundo ele, "houve três momentos fundamentais no capitalismo, cada um marcando uma expansão dialética com relação ao estágio anterior. O capitalismo de mercado, o estágio do monopólio ou do imperialismo, e o nosso, erroneamente chamado de pós-industrial, mas que poderia ser mais bem designado como o do capital multinacional. (...) Esse capitalismo tardio, ou multinacional, ou de consumo, longe de ser inconsistente com a grande análise do século XIX de Marx, constitui, ao contrário, a mais pura forma de capital que jamais existiu, uma prodigiosa expansão do capital que atinge áreas até então fora do mercado". Nessa fase, segundo o autor, deve-se ressaltar, a "ascensão das mídias e da indústria da propaganda"'

No capitalismo de mercado, primeiro momento, tivemos o incremento do capital industrial, principalmente em mercados nacionais (período entre 1700 e 1850); no segundo momento, o estágio do monopólio ou impe-

\section{A AUTORA \\ Maria Aparecida Baccega \\ Professora Livre-Docente do Departamento de Comuni- cações e Artes da ECA-USP. Diretora Editorial da Re- vista Comunicação \& Educação.} Teorias da globalização. Rio de Janeiro: Civilização Brasileira, 1995. p.43

2. JAMESON, Fredric. A lógica cultural do capitalismo tardio. In: Pós-modernismo. A lógica cultural do capitalismo tardio. (Trad. Maria Elisa Velasco). São Paulo: Ática, 1996. p.61 
rialismo, a abertura de mercados mundiais, organizados em torno de nações-estado, com exploração das nações colonizadoras sobre as colonizadas, as quais forneciam matérias-primas e mão de obra barata; e, atualmente, na fase pós-industrial do capital multinacional - o terceiro momento - temos o crescimento de corporações internacionais e conseqüente superação das tradicionais fronteiras nacionais. Evidentemente, cada uma dessas totalidades, heterogêneas pela sua própria natureza, engendrou culturas diferentes.

Resultado da fase contemporânea do capital, a cultura que vivemos hoje tem sido chamada de pós-moderna. Nela, fragmentação e globalização se manifestam num processo de complementação que se dá no âmbito do mercado. Como lembra Martín-Barbero ${ }^{3}$, o global é o espaço novo produzido pelo mercado e pelas tecnologias, que dependem dele para sua permanente expansão.

O mundo, que sempre esteve em permanente mudança, hoje tem multiplicada a rapidez dessas mudanças, devido ao avanço das tecnologias. É esse o cenário que possibilita o fortalecimento das corporações internacionais e conseqüente ruptura das fronteiras nacionais, atingindo "áreas até então fora do mercado".

Essa realidade tem como sustentáculo os meios de comunicação, mediadores privilegiados entre nós e o mundo, e que cumprem o papel de "costurar" as diferentes realidades. São os meios de comunicação que divulgam, em escala mundial, informações (fragmentadas) hoje tomadas como conhecimento, construindo, desse modo, o mundo que conhecemos. Trata-se, na verdade, do processo metonímico - a parte escolhida para ser divulgada, para ser conhecida, vale pelo todo. É como se "o mundo todo" fosse constituído apenas por aqueles fatos/notícias que chegam até nós.

Consideramos, porém, que informação não é conhecimento. Poderá até ser um passo importante. O conhecimento implica crítica. Ele se baseia na inter-relação e não na fragmentação. Todos temos observado que essa troca do conhecimento pela informação tem resultado numa diminuição da criticidade.

$\mathrm{O}$ conhecimento é um processo que prevê a condição de reelaborar o que vem como um "dado", possibilitando que não sejamos meros reprodutores; inclui a capacidade de elaborações novas, permitindo reconhecer, trazer à superfície o que ainda é virtual, o que, na sociedade, está ainda mal desenhado, com contornos borrados. Para tanto, o conhecimento prevê a construção de uma visão que totalize os fatos, inter-relacionando todas as esferas da sociedade, percebendo que o que está acontecendo em cada uma delas é resultado da dinâmica que faz com que todas interajam, dentro das possibilidades daquela formação social, naquele momento histórico; permite perceber, enfim, que os diversos fenômenos da vida social estabelecem suas relações tendo como referência a sociedade como um todo. Para tanto, as informações - fragmentadas - não são suficientes.

Os meios de comunicação, sobretudo a televisão, ao produzirem essas informações, transformam em verdadeiros espetáculos os acontecimentos selecionados para se tornarem notícias. Já na década de 60, Guy Debord percebia "na vida con-

3. MARTÍN-BARBERO, Jesús. La comunicación plural: alteridad y socialidad. Dia-logos de la comunicación. Lima: Felafacs, n.40, set. de 1994, p.73-79 
temporânea uma 'sociedade de espetáculo', em que a forma mais desenvolvida de mercadoria era antes a imagem do que o produto material concreto", e que, "na segunda metade do século XX, a imagem substituiria a estrada de ferro e o automóvel como força motriz da economia"4.

Por sua condição de "espetáculo", parece que o mais importante na informação passa a ser aquilo que ela tem de atração, de entretenimento. Não podemos nos esquecer, porém, de que as coisas se passam desse modo exatamente para que o conhecimento - e, portanto, a crítica - da realidade fique bastante embaçada ou simplesmente não se dê.

O conhecimento continua a ser condição indispensável para a crítica. A informação, que parece ocupar o lugar desse conhecimento, tornou-se, ela própria, a base para a reprodução do sistema, uma mercadoria a mais em circulação nessa totalidade ${ }^{5}$.

A confusão entre conhecimento e informação, entre totalidade e fragmentação leva à concepção de que a informação veiculada pelos meios é suficiente para a formação do cidadão, de que há um pressuposto de interação entre os meios e os cidadãos e de que todas as vozes circulam igualmente na sociedade.

É a chamada posição liberal, a qual parece esquecer-se de que idéias, para circular, precisam de instrumentos, de suportes - rádio, televisão, jornal etc. - que custam caro e que, por isso, estão nas mãos da elite dominante, daqueles que detêm o capital. E que é essa elite, também, a detentora do lugar de prestígio, a partir do qual emite seu "discurso competente"6.

Nesse espaço conhecido como "sociedade de consumo, sociedade das mídias, sociedade da informação, sociedade eletrônica ou high-tech e similares"”, ganham destaque as questões referentes ao significante/significado/significação, ao simulacro, à imagem de maneira geral. A nós nos parece que o que devemos discutir é menos a questão do estético e/ou da estetização dos fatos e acontecimentos sociais que os meios de comunicação promovem, e mais uma visão da História e do sujeito. É necessário que recoloquemos as questões das relações de poder, das novas formas de exercício desse poder nesse cenário da contemporaneidade, onde descontinuidade histórica e sobreposição de modos de produção - de capitalismo internacional a resquícios de relações quase feudais, onde a questão da terra é uma questão não resolvida - se fazem presentes. É preciso trazer à tona a importância do resgate da individualidade, e não a exacerbação do individualismo.

Comunicação é produção social de sentido. E esse sentido se constrói nas relações sócio-históricas dessa sociedade pós-industrial. Os meios de comunicação, que são da natureza dessa sociedade, atuam como fator de coesão social tanto nas

4. CONNOR, Steven Cultura pós-moderna. Introdução às teorias do contemporâneo. (Trad. Adail Ubirajara Sobral e Maria Stela Gonçalves). São Paulo: Loyola, 1992. p.48.

5. Comunicação do Prof. Dr. Celso Frederico em Seminário interno re: lizado no Departamento de Comunicações e Artes da ECA-USP, em 1996.

6. Conforme conceituado por CHAUÍ, Marilena. Cultura e democracia. O discurso competente e outras falas. 3.ed. São Paulo: Moderna, 1982.

7. JAMESON, Fredic. A lógica cultural... op. cit. p.29. 
pequenas regiões, no nível interno e/ou no nível de suas relações com o mundo, quanto em sociedades com grande complexidade social e cultural.

Atuando privilegiadamente no cotidiano, eles editam o mundo, agendam temas. Por essa caraterística, a comunicação entra no processo permanente de produção de significado, portanto, de construção da realidade, em todas as suas manifestações, quer sejam culturais, econômicas ou políticas. Como lembra Martín-Barbero $^{8}$, "até mesmo a aprendizagem de toda sofisticação hoje passa pela TV: publicidade, videoclipes de música que mostram, por exemplo, o que se está fazendo de mais avançado com computador. A comunicação é produção social de sentido, de prazer, de estética, de cidadania".

Os discursos, base na qual se assentam os meios de comunicação, permanentemente reconfigurados na realidade histórica, onde se constrói seu significado, são amplificados para todo o mundo. São vozes e pontos de vista escolhidos para divulgação, que nos dão a base para nos inserirmos no mundo. A comunicação passou a ser, então, uma das instituições que "levam a pensar", sobretudo pela aura de conhecimento agregada à informação.

Ocupando espaços e promovendo silêncios, o discurso tem seu poder ampliado pelos meios de comunicação, os quais dão voz a algumas posições e silenciam outras. O prestígio do discurso, a "autoridade" de quem emite, o lugar do discurso, enfim, são fundamentais para sua divulgação com caráter de veracidade. Logo, ele está no centro das relações de poder.

$\mathrm{O}$ avanço da tecnologia, que está na base da discussão sobre informação $\mathrm{X}$ conhecimento, trouxe, segundo Sílio Boccanera ${ }^{9}$, repórter de televisão, correspondente internacional, novas exigências também para o jornalista. Para ele, as mudanças na área de tecnologia de televisão obrigam o jornalista a agir com uma instantaneidade que não existia no passado. Durante a Guerra do Vietnã, por exemplo, que terminou em 1975, a primeira grande guerra acompanhada pela televisão, o repórter que cobria a guerra usava filme. $O$ vídeo não existia. Esse filme precisava ser revelado. Era, então, enviado para os Estados Unidos ou para a Europa, onde era montado e apresentado nesses países. Geralmente quatro dias após o acontecimento, tempo de duração desse processo. Hoje, estamos familiarizados com coberturas internacionais em tempo real: o fato está acontecendo e nós estamos vendo-o em nossas casas. A tecnologia permite que o evento seja acompanhado na hora em que acontece.

Por isso, o profissional, ao ser destacado para cobrir um evento para a televisão, tem menos tempo para pensar sobre o que significa o fato que ele está cobrindo. O tempo de reflexão é diminuído: tanto o do jornalista quanto o do editor, na redação. Se acontece uma crise no Oriente Médio, por exemplo, o jornalista tem que dar sentido para aquilo com muita rapidez. Só com conhecimento ele se-

8. MARTÍN-BARBERO, Jesús. Entrevista à revista Comunicação \& Educação. São Paulo, 28/08/97. (Inédita), 9. Reflexões do jornalista Sílio Boccanera em sua Palestra no Curso Internacional de Extensão Universitária América Latina, Comunicação e Cultura, realizado na Escola de Comunicações e Artes da USP, em 5 de novembro de 1997. 
rá capaz de contextualizar o que está ocorrendo, para que possa construir um discurso, um texto que percorrerá o mundo. Caso contrário, a notícia não se sustentaria. Afinal, nem a transmissão de jogos de futebol pela televisão aceita a descrição primária.

A repercussão do acontecimento também é instantânea. Lideranças políticas dos vários países são entrevistadas por outros jornalistas, colegas do que está no local do acontecimento. Decisões são tomadas com muita rapidez. A chamada opinião pública internacional, através de suas organizações, tomam posição.

Isso tudo faz com que o início desse processo, que é a apuração da notícia, a coleta da informação seja extremamente importante. É preciso que o jornalista consiga perceber e relacionar as várias partes de que se compõe o acontecimento. É preciso, também, que o profissional tenha "a condição de reelaborar o que vem como um 'dado"”, reconhecer "o que está ainda mal desenhado, com contornos borrados", construir "uma visão que totalize os fatos, inter-relacionando todas as esferas da sociedade, percebendo que o que está acontecendo em cada uma delas é resultado da dinâmica que faz com que todas interajam, dentro das possibilidades daquela formação social, naquele momento histórico", que, como dissemos, são características do conhecimento.

Isso tudo exige do jornalista uma preparação prévia muto mais intensa do que foi no passado. Sílio Boccanera chama esse conhecimento de "super-informação". Cada um tem que estar com alto grau de "super-informação" já antes de chegar ao local. Simplesmente porque no local da cobertura não haverá tempo suficiente para absorver e apreender tudo. Esse conhecimento é um processo contínuo. As pessoas têm que estar permanentemente lendo, informando-se, ouvindo rádio, indo ao treatro, ao cinema etc.

Hoje já é possível, tecnicamente, numa cobertura de guerra, acompanhar, por exemplo, um ataque de mísseis com uma câmera a bordo de um deles enquanto ele se dirige a um alvo. O telespectador, em casa, jantando, pode observar esse míssil chegando ao alvo, o qual pode ser uma escola cheia de crianças. E assistir ao vivo o que acontece. Quem vai relatar esse evento é o jornalista. Ele tem que estar, portanto, muito mais preparado do que está hoje.

Outra questão que conhecimento versus informação coloca, é a que se refere ao relato da informação. Há um forte contraste entre a abordagem que dá ênfase ao que está acontecendo e a que dá ênfase ao aspecto de entretenimento. Esse último estilo destaca o lado do show, da atração, e já vem sendo conhecido como infotainement (informação-entretenimento). Ou seja, é a informação não pelo relato da totalidade do que ocorre, mas sim a informação pelo espetáculo, como já advertia Guy Debord, citado anteriormente. .

Mesmo com toda a agilidade, a televisão não ocupa o lugar da imprensa escrita. A imprensa escrita sempre vai existir. É ela que dá o contexto e explica melhor o que a imprensa eletrônica, pela própria natureza de sua linguagem, não consegue explicar. "Quem só se informa pela televisão, não se informa. É precioso ler textos, não só os da imprensa escrita, mas todos os tipos de texto, permanentemente", diz Sílio Boccanera. 
A informação, que tem na televisão sua divulgação mais efetiva, realmente não é conhecimento. Apenas procuram nos convencer do contrário para que nossa crítica à realidade diminua. Ou quase desapareça.

Os meios de comunicação, como procuramos mostrar, estão incorporados como educadores privilegiados. Enquanto ainda falamos em educação para os meios, ou leitura crítica dos meios, o campo comunicação/educação já está constituído. Já não se trata mais, portanto, de discutir se devemos ou não utilizar os meios de comunicação no processo educacional ou de procurar estratégias de educação para os meios. Trata-se de constatar que, educadores primeiros, são eles que estão construindo a cidadania.

Ser cidadão é estar no mundo e com o mundo (parafraseando Paulo Freire). E para conhecer melhor o mundo, torna-se fundamental desvelar os mecanismos de edição utilizados pelos meios, para inter-relacionarmos fatos/edição/construção da cidadania. Para isso, uma das coisas fundamentais é que comecemos a tirar a poeira de cada uma das camadas que formam a nossa história (a História dos que fazem a História), resgatá-las, apropriarmo-nos delas (antes que outros definitivamente o façam e nós as percamos) para com ela construirmos o futuro onde habitarão os cidadãos que queremos.

O conhecimento, que não exclui a informação, poderá colaborar muito A escola, desvelando os processos de produção da notícia e edição do mundo, pode ajudar a transformar a informação veiculada pelos meios de comunicação em conhecimento.

\section{ARTIGOS NACIONAIS}

O jornalista Luciano Martins Costa, editor-executivo de O Estado de S. Pau$l o$, nos fala do jornal e do jornalista nos novos tempos, em $O$ jornal e o jornalista de amanhã. "Passada a febre da reengenharia", hoje se tem como certo que é necessário "substituir o deslumbramento com os recursos técnicos por políticas de valorização dos recursos humanos". São novas formas de gestão, que compreendam que "o jornal é um negócio de educação"10, que "a edição deve se voltar muito mais para a comunidade do que para os agentes econômicos ou do poder político". É fundamental, portanto, "a sólida formação ética" do jornalista. E, segundo o autor, tudo isso (e mais) é necessário para que o jornal se torne efetivamente um "negócio de educação". "O jornal precisa ser capaz de agregar à função informativa a função de envolvimento, de modo a transformar notícia em conhecimento. As tecnologias são ferramentas, algumas delas de utilidade duvidosa."

Para essa transformação da notícia em conhecimento, que papel cumpre o jornalismo didático? Desse tema tratam Clóvis de Barros Filho ${ }^{11}$ e Antônio Dal Fabbro em Jornalismo didático e agenda do leitor. Como lembram os autores,

10. Ver, do mesmo autor, Um brinde pela educação. Comunicação \& Educação. São Paulo: CCA-ECAUSP/Moderna, n.3, maio/ago. de 1995. p.43-46.

11. Também é autor de: Agenda setting e educação. Comunicação \& Educação. São Paulo: CCA-ECAUSP/Moderna, n.5, jan../abr. de 1996. p.27-33. 
"segundo a hipótese da agenda setting, os temas mais presentes nos meios de comunicação serão os temas mais discutidos na agenda pública do universo social do receptor", o que, relacionado ao jornalismo didático, deveria constituir-se em "efeito democratizador" dos meios de comunicação. Mas, lembram os autores, "o agendamento permanente de temas selecionados pressupõe o desagendamento sistemático de temas preteridos pelos mecanismos de seleção editorial”. Então, como ficamos? Para responder essas questões, os autores apresentam a pesquisa que fizeram com o público, em abril de 1997, quando os precatórios eram pauta obrigatória em toda a mídia. Vale a pena ler.

Ter acesso ao conhecimento é ser cidadão. Como construir a cidadania em tempos de globalização, processo que "é universal mas é excludente, é global mas se materializa no local, engendrando novas formas de sensibilidade", constituindo o que vem sendo chamado de glocalização. É disso que trata Maria Salett Tauk Santos, em Gestão da comunicação no desenvolvimento regional. A autora nos apresenta, a partir dessas questões, o Programa Reformulado de Apoio ao Pequeno Produtor Rural (PAC/FUMAC), mostrando a importância da "participação enquanto processo de comunicação" e de uma gestão adequada dos processos comunicacionais para o êxito do desenvolvimento local que, segundo ela, "passa por uma nova cultura política". E aí "as novas tecnologias e os meios de comunicação, enquanto manifestações do global, podem ajudar a suprir uma lacuna extensa de dívida social com as populações menos privilegiadas", levando em consideração, em sua atuação, "as demandas da comunidade local". Ou, como afirmou Luciano Martins Costa no artigo citado acima, "a palavra de ordem na imprensa regional é: foco na comunidade", pois os jornais regionais "descobriram que não precisam repetir as manchetes da chamada grande imprensa para merecer a atenção dos seus leitores: a vida comunitária tem seus atrativos e o editor regional perde o medo de parecer provinciano". Trata-se da concretização da "visão do desenvolvimento local como espaço de mediações do global/local e do local com a esfera de produção de sentido e da ação", como diz Maria Salett.

$O$ adolescente diante da telenovela, de Maria de Fátima Faila Elias, comprova, mais uma vez, o papel fundamental do sujeito receptor na construção do significado das "mensagens" dos meios de comunicação. Deixando de lado o que costumamos chamar de achometro, a autora vai ao encontro de um grupo de adolescentes da zona urbana e outro da zona rural, para verificar como se dá a interação de cada um desses grupos com as telenovelas. Será que os adolescentes "mantêm sonhos e ilusões baseados na temática das novelas?" Essa é apenas uma das perguntas que Maria de Fátima vai responder no seu artigo. Lendo, vamos percebendo com clareza a importância da mediação do "local" na "produção do sentido" dos produtos que o avanço da tecnologia possibilita.

É de tecnologia que nos falam Aldete Büchler Zorrón Berlinck e José Augusto Mattos Berlinck, em Terceira idade e tecnologia. O Brasil, atualmente, conta com maior número de pessoas de terceira idade, as quais vivem num mundo "cada vez mais informatizado", onde "as trocas de informação estão se realizando com características e técnicas diversas". E elas precisam conhecer essas tecnolo- 
gias, para usá-las em seu benefício, apropriando-se delas para tornarem suas vidas mais amenas. É necessário que a tecnologia "passe a ser um saber para um fazer melhor". Neste artigo, os autores apresentam, além das premissas a partir das quais trabalhar essa problemática, um programa de atuação, que vem tendo bastante êxito em sua aplicação.

\section{ARTIGO INTERNACIONAL}

Cidade virtual: novos cenários de comunicação é o artigo de Jesús MartínBarbero que traduzimos para este número. Ele nos mostra "a impossibilidade de continuar pensando separadamente os processos da modernização industrial e tecnológica das dinâmicas culturais da modernidade", fatores constituintes dos "novos cenários da comunicação". Consideramos que esse artigo serve de cenário para a leitura deste número de Comunicação \& Educação e de chave para o conhecimento da contemporaneidade.

\section{ENTREVISTA}

Segundo Beth Carmona, diretora de programação da TV Cultura de São Paulo, em entrevista exclusiva à Comunicação \& Educação, a TV Cultura tomou a dianteira na discussão da TV educativa no Brasil. Entendendo de forma ampla o educativo, ela se destaca na produção de uma programação infanto-juvenil que alcança elevados índices de audiência, inclusive para os padrões internacionais. Isso confirma que o público gosta de boa programação. Para ela, a oferta de programação de qualidade deveria ser intensificada também pelos canais comerciais, que são, afinal, concessão pública. A entrevista com Beth Carmona acrescenta conhecimento, sobretudo no sentido de se contextualizar a dicussão e a polêmica sobre a qualidade da programação da televisão, neste momento em que as emissoras pautam cada vez mais sua grade de programas pelo que há de pior, de mais preconceituoso e de vulgarização da imagem da mulher e do sexo e pelo uso abusivo e descontextualizado da violência.

\section{CRÍTICA}

O cinema nacional ganhou de fato, nestes últimos dois anos, produções expressivas que alavancam novas inciativas e projetos, demonstrando a capacidade e criatividade de nossos cineastas. Guerra de Canudos, filme de Sérgio Rezende, é o tema da crítica deste número. Adílson Odair Citelli destaca a oportunidade das inúmeras produções e atividades artísticas e culturais que, no aniversário do centenário da guerra dos sertanejos nordestinos pelo direito à sua utopia, o tema ainda suscita, mostrando-se atual. $\mathrm{O}$ filme envolveu muita pesquisa histórica, recomposição de cenário e figurinos que exigiu dedicação de inúmeros profissionais e contou com o engajamento da população da região de Junco do Salitre, que pôde, através do filme, recontar e reapropriar-se da história de seus antepassados. 
O Festival de Gramado é tema do artigo de Júlia Mirabal, jornalista cubana, especializada em cultura, que esteve no Brasil especialmente para cobrir o evento. A autora destaca a qualidade da produção de curtas-metragens, principalmente $O$ Pulso, de José Pedro Goulart e Decisão, de Leila Hipólito, e vê um certo “desnível qualitativo" dos filmes de longa metragem, chamando a atenção, sobretudo, para a falta de qualidade dos roteiros. Segundo Júlia, Gramado é um espaço muito importante para a cinematografia latino-americana.

\section{DEPOIMENTO}

Paulo Augusto da Silva, ex-editor de Encartes, suplemento cultural do Jornal de Natal, conta sua experiência profissional à frente desse órgão da imprensa nordestina. Mostra como a produção cultural da comunidade pode ser valorizada ao ganhar espaço nos meios de comunicação, permitindo que a produção local exercite seu direito de expressão e liberando o suplemento da reprodução de matérias dos grandes jornais, nas quais somente as expressões artístico-culturais privilegiadas pela grande mídia têm espaço. Pode-se verificar, mais uma vez, a importância da prática do regional, como discutido nos artigos anteriores.

\section{EXPERIÊNCIA}

A literatura de Graciliano Ramos, em Alexandre e outros heróis, motivou a professora Cláudia Cavalcante a preparar, com seus alunos da terceira série do primeiro grau, o trabalho em literatura e produção de textos que percorreu um semestre inteiro. As crianças reapropriaram-se da fator lúdico que existe no contar histórias, descobriram novas palavras, perceberam que elas fazem sentido dentro de um contexto cultural dado e puderam produzir seus próprios livros de contos.

\section{POESIA}

Santa clara, padroeira da televisão é a poesia/música de Caetano Veloso, que Comunicação \& Educação oferece para seus leitores. A poesia como linguagem metafórica e síntese de tantas palavras e sentidos pode nos ajudar a refletir sobre o destaque que esse meio de comunicação tem na vida da sociedade.

\section{SERVIÇOS}

Como lembra Maria Salett, na contemporaneidade, as empresas procuram, "em parceria com o setor público e as comunidades, alternativas locais" para a solução de problemas. A Fiat decidiu ajudar a ganhar a batalha da educação. Ela faz do programa Moto Perpétuo sua ponte com a comunidade, alavancando a escola como instituição que requer atenção privilegiada. É o que Tarcísio Luís D'Almeida Alves mostra em Contribuição da Fiat para a educação. 
O Congresso Internacional de Comunicação e Educação é a principal atividade para 1998 do Núcleo de Comunicação e Educação da Escola de Comunicações e Artes da USP. Seu coordenador, Prof. Dr. Ismar de Oliveira Soares, trata em seu artigo - Núcleo de Comunicação e Educação promove Congresso Internacional - dos objetivos e da importância deste trabalho e de outros que o Núcleo vem desenvolvendo.

\section{BOLETIM BIBLIOGRÁFICO}

Nesta edição há, em Videografia, sugestões interessantes da Profa. Maria Ignês Carlos Magno para o trabalho com o vídeo em sala de aula, na qual destaca o trabalho com a linguagem cinematográfica e sua inerente intertextualidade. Na Bibliografia sobre a telenovela brasileira, Anamaria Fadul destaca títulos novos e antigos como contribuições expressivas ao estudo desse tipo de teleficção. Em Bibliografia na área de Comunicação e Educação o leitor encontra as últimas contribuições de especialistas e pesquisadores, compondo um expressivo conjunto de obras, fundamentais para alicerçar pesquisas neste campo.

Resumo: $\mathrm{O}$ artigo trata da contemporaneidade, mostrando a cultura chamada pós-moderna como resultado da fase atual do capitalismo internacional. Aponta a informaçāo, fragmentada, como caracteristica dessa fase e discute as diferenças entre informação e conhecimento, considerado indispensável para o exercício da critica e da cidadania. Ressalta o papel da tecnologia, mostrando que a rapidez na divulgação da informação, que ela possibilita, implica a necessidade de uma visão da totalidade, característica do conhecimento, tanto para o profissional de comunicaçāo quanto para os receptores. Destaca, ainda, o papel da escola no processo de transformação da informação em conhecimento.

Palavras-chave: pós-moderno, capitalismo, meios de comunicação, conhecimento, informação, tecnologia
Abstract: The article deals with contemporaneousness, revealing a so-called post-modern culture as a result of the current phase of international capitalism. It points to information, fragmented, as characteristic of this phase and discusses the differences between information and knowledge, considered as indispensable in order for one to practice criticism and citizenship. It stresses the role of technology, showing that quickness at divulging information, something that this technology allows, implies on the need for a view of the totality, characteristic of knowledge, both for the communications professional as well as for the receptors. The article also stresses the role of the school in the process of transforming information into knowledge.

Keywords: post-modern, capitalism, mass communications, information, technology 